\title{
Platelet-neutrophil interactions as drivers of inflammatory and thrombotic disease
}

\author{
Ton Lisman ${ }^{1}$
}

Received: 27 July 2017 / Accepted: 27 October 2017 / Published online: 25 November 2017

(C) The Author(s) 2017. This article is an open access publication

\begin{abstract}
Neutrophils are well known for their role in infection and inflammatory disease and are first responders at sites of infection or injury. Platelets have an established role in hemostasis and thrombosis and are first responders at sites of vascular damage. However, neutrophils are increasingly recognized for their role in thrombosis, while the immunemodulatory properties of platelets are being increasingly studied. Platelets and neutrophils interact during infection, inflammation and thrombosis and modulate each other's functions. This review will discuss the consequences of platelet-neutrophil interactions in infection, thrombosis, atherosclerosis and tissue injury and repair.
\end{abstract}

Keywords Platelet · Neutrophil · Inflammation ·

Thrombosis · Ischemia

\section{Introduction}

Platelets are anuclear cell fragments that circulate in healthy humans at about 150,000-400,000 per microliter blood. Platelets are well known for their role in thrombosis and hemostasis. Inherited or acquired defects in platelet count and/or function can be associated with bleeding complications. Conversely, platelets are key players in thrombotic disease and drugs inhibiting platelet function are vital in treatment and prevention of arterial thrombotic diseases such as

Ton Lisman

j.a.lisman@umcg.nl

1 Surgical Research Laboratory and Section of Hepatobiliary Surgery and Liver Transplantation, Department of Surgery, University of Groningen, University Medical Center Groningen, BA33, Hanzeplein 1, 9713, GZ Groningen, The Netherlands myocardial infarction and stroke. Recent studies show that platelets have many functions beyond physiological or pathological thrombus formation. They play a role in inflammation, are effectors of injury in a variety of pulmonary disorders and syndromes, facilitate tissue repair and act in the growth and development of metastases of various cancers (Xu et al. 2016). Although platelets can exert some of their functions individually, it is increasingly recognized that interactions between platelets and other circulating cell types are crucial for many of their functions. In this review, I will address the interaction of platelets with neutrophils and the role of this interaction in inflammation and infection, thrombosis, atherosclerosis and tissue injury and repair.

\section{Platelet-neutrophil complexes}

It has been long known that circulating platelet-neutrophil complexes are present in a wide range of inflammatory conditions including bacterial infections and sepsis (Gawaz et al. 1995), inflammatory bowel disease (Pamuk et al. 2006), sickle cell disease (Polanowska-Grabowska et al. 2010), atherosclerosis and coronary syndromes (Ott et al. 1996; Maugeri et al. 2014) and pulmonary inflammatory syndromes (Gresele et al. 1993; Caudrillier et al. 2012). Platelets interact with neutrophils by multiple interactions including platelet P-selectin binding to neutrophil P-selectin glycoprotein ligand-1 (PSGL-1) (Hamburger and McEver 1990; Moore et al. 1995) and platelet glycoprotein Ib $\alpha$ binding to neutrophil MAC-1 (Simon et al. 2000). P-selectin exposure on the platelet surface requires platelet activation. Indeed, platelet-neutrophil complexes have been used as markers for platelet activation and, surprisingly, these complexes appear better markers of in vivo platelet activation compared to direct assessment of platelet P-selectin expression (Michelson et al. 2001). The 
generation of platelet-neutrophil complexes in vivo is facilitated by margination of platelets and neutrophils to the periphery of blood vessels as a consequence of displacement of erythrocytes to the central part of the vessels (Goldsmith and Spain 1984; Goldsmith et al. 1999). This margination process greatly enhances the possibility of collisions between neutrophils and platelets. Stable platelet-neutrophil complexes require platelet activation that may occur in solution but could also occur as a result of platelet adhesion to activated endothelial cells or a vascular injury. Platelets are capable of adhering to activated or injured endothelium from flowing blood and the efficacy of platelet adhesion actually increases with increasing shear rate (Remuzzi et al. 1985; Houdijk et al. 1986). The unique biophysical properties of the interaction of platelet glycoprotein Ib $\alpha$ with collagen- or endothelial cellbound von Willebrand factor (VWF) underlie shear stressmediated enhancement of platelet deposition (Ciciliano et al. 2015). In contrast, neutrophils, although able to adhere to activated endothelial cells, become less efficient in adhering with increasing shear (Kuijper et al. 1996). Platelets therefore facilitate neutrophil adhesion to activated or injured endothelium at higher shear and thereby promote leucocyte transmigration across the endothelium. A recent study showed that neutrophil adhesion to activated platelets proceeds via long membrane protrusions that extend from adhered platelets and are formed under conditions of flow both in vitro and in vivo (Tersteeg et al. 2014). These elongated membrane structures (referred to as flow-induced protrusions or FLIPRs) were shown to bind neutrophils in a P-selectin/ PSGL-1-dependent manner. This interaction led to neutrophil activation and transfer of microparticles from the FLIPR to the neutrophil. Interestingly, the authors suggested that neutrophil-platelet microparticle complexes may also occur in vivo, and that part of the previously reported neutrophilplatelet complexes are in fact neutrophil-platelet microparticle complexes. In the following sections, I will address functional consequences of platelet-neutrophil interactions.

\section{Platelet-neutrophil interactions in inflammation and infection}

Neutrophils are key first responders to sites of injury and infection and are increasingly recognized as actors in chronic inflammatory states (Deniset and Kubes 2016; Soehnlein et al. 2017). Neutrophils combat invading pathogens by a combination of phagocytosis, generation of reactive oxygen species and release of neutrophil extracellular traps (NETs). The platelet-neutrophil interplay is key in all these inflammatory responses, as it helps localizing platelets to inflammatory sites, potentiates production of oxygen radicals and is key in neutrophil activation to release NETs (Page and Pitchford 2013).
It has been shown that neutrophils continuously patrol the vasculature for activated platelets to initiate inflammatory responses (Sreeramkumar et al. 2014). Activated platelets are crucial in neutrophil-mediated inflammatory responses, as depletion of either cell type decreases mortality in models of pathological inflammation including acute lung injury (Looney et al. 2009) and sepsis (Sreeramkumar et al. 2014). Interactions between P-selectin and PSGL-1 and glycoprotein $\mathrm{Ib} \alpha$ and MAC-1 have been shown to drive platelet-neutrophil interactions under inflammatory conditions (Sreeramkumar et al. 2014; Wang et al. 2017). Interestingly, while depletion of platelets decreases neutrophil recruitment under inflammatory conditions, the reverse is also true (Clark et al. 2007; Sreeramkumar et al. 2014). Thus, the observation that platelet influx is also decreased when neutrophils are depleted suggests that the model that neutrophils scan inflammatory sites for activated platelets might be too simplified.

Besides a role in neutrophil localization, activated platelets initiate or amplify various neutrophil responses including phagocytosis and production of oxygen radicals and production of NETs. Such responses are initiated by direct contact but also by release of soluble mediators such as CCL5 and platelet factor 4 (von Hundelshausen et al. 2005; Pervushina et al. 2004). Conversely, neutrophils also release soluble mediators such as cathepsin $\mathrm{G}$ and elastase that enhance platelet responses by activation of protease-activated receptors on platelets (Selak 1992; Sambrano et al. 2000; Mihara et al. 2013). Interestingly, these neutrophil-derived enzymes are also negative regulators of platelet adhesion as they may proteolyse VWF (Bonnefoy and Legrand 2000).

Platelet interactions have been shown to enhance the phagocytic capacity of neutrophils towards various bacteria in vitro (Assinger et al. 2011; Peters et al. 1999; Hurley et al. 2015). In addition, thrombocytopenia increases the bacterial load in animal models of bacterial infection (de Stoppelaar et al. 2014; van den Boogaard et al. 2015). In addition, platelets may enhance the release of reactive oxygen species and myeloperoxidase further contributing to pathogen killing (Zalavary et al. 1996; Gros et al. 2015b). However, under certain experimental conditions, platelets downregulate the oxidative burst and the action of platelets in the inflammatory response and therefore appears contextdependent (Lecut et al. 2012). Platelets are also key in the formation of neutrophil extracellular traps (NETs) (von Bruhl et al. 2012; Clark et al. 2007). NETs are extracellular webs generated upon neutrophil activation, consisting of neutrophil DNA with various proteins such as histones attached (Brinkmann et al. 2004). NETs capture and kill pathogens directly and inactivate virulence factors by elastase present within the NET. Platelet-mediated NET formation requires platelet-neutrophil interactions by P-selectin/PSGL-1 interactions or by binding of neutrophil $\beta 2$ integrins with GPIb $\alpha$ or $\alpha \operatorname{IIb} \beta 3$ on the platelet (Jenne et al. 2013; Etulain et al. 2015; 
Caudrillier et al. 2012; Carestia et al. 2016). In experimental sepsis models, activation of platelet TLR4 was shown to be key in the generation of NETs (Clark et al. 2007). Furthermore, platelets stimulate neutrophil transmigration over the endothelium, likely by a combination of assisting neutrophil adhesion to the endothelium and enhancing endothelial cell permeability (Gros et al. 2015a). Finally, platelets stimulate the formation of various leukotrienes by neutrophils in an intriguing mechanism involving transfer of the arachidonic acid metabolite 12-HETE from platelet to neutrophils, which further process this molecule to bioactive leukotrienes (Marcus et al. 1984, 1987, 1988). This transcellular arachidonic acid pathway presumably requires platelet-neutrophil contact given the key role of P-selectin in this process (Maugeri et al. 1994). Leukotrienes such as LTC4, LTD4, LTE4, LTB4 and 12- and 20-diHETE have various downstream effects including enhancement of vascular permeability, modulation of smooth muscle cell contractility and chemo-attraction (Peters-Golden and Henderson 2007). Interestingly, the transcellular arachidonic acid metabolism is bidirectional, as platelets also use arachidonic acid released from neutrophils to increase 12 -HETE production (McCulloch et al. 1992).

\section{Platelet-neutrophil interactions in thrombosis}

Animal models of thrombosis have demonstrated a key role of neutrophils in venous and arterial thrombosis. In a model of venous thrombosis induced by flow restriction, leukocytes (predominantly neutrophils) have been shown to crawl along and adhere to the surface of (activated) endothelial cells, eventually forming an almost continuous layer on the vascular endothelium (von Bruhl et al. 2012). These leukocytes have been demonstrated to initiate and propagate venous thrombosis in this model. Similarly, neutrophils have been shown to be the first responding cells in response to arterial injury induced by a laser (Darbousset et al. 2012). However, in other models, platelets were the first responding cells, with leukocyte influx critically dependent on deposited platelets (Palabrica et al. 1992; Gross et al. 2005). Although it has been long recognized that leukocytes contribute to activation of coagulation in thrombosis, the mechanisms involved are still incompletely understood. Importantly, a recent study using a mouse model of spontaneous venous thrombosis found that neutrophil depletion did not affect thrombosis development despite the observation that neutrophils were abundant within the thrombus, indicating that the role of neutrophils in thrombosis may be context-dependent (Heestermans et al. 2016).

At least three distinct mechanisms may be involved in platelet-dependent, neutrophil-mediated induction of thrombosis. First, neutrophils have been demonstrated to transfer tissue factor, the physiological initiator of coagulation, to platelets during thrombus formation in vitro (Giesen et al. 1999). This transfer proceeds via TF-containing microparticles derived from neutrophils and is dependent on TF and microparticle CD15 (Rauch et al. 2000). Also in vivo, TFbearing microparticles have been shown to be incorporated into thrombi early after vascular injury and to drive thrombus formation (Gross et al. 2005). During thrombus formation, TF requires 'decryption', i.e., transformation from a circulating non-coagulant, to a thrombus-associated coagulant form (Chen and Hogg 2013). Decryption requires thiol isomerase activity by, for example, protein disulfide isomerase.

The 'blood-borne' TF concept challenges the dogma that tissue factor is normally not located on cells in contact with blood and the source and quantity of blood borne TF is subject to ongoing debate (Butenas et al. 2005; Cimmino et al. 2011). For example, while some have found that platelets contain TF (Muller et al. 2003; Schwertz et al. 2006; Panes et al. 2007; Camera et al. 2003), others failed to reproduce these findings (Bouchard et al. 2010; Osterud and Olsen 2013). Distinct mechanisms for platelet TF expression have been proposed: (1) acquisition from leukocyte-derived microparticles (Giesen et al. 1999), (2) storage in platelet $\alpha$ granules (Muller et al. 2003) and (3) de novo synthesis from mRNA stored within the (anucleate) platelet (Schwertz et al. 2006). However, all these findings have been questioned with reference to an inadequate methodology used in these studies. Similarly, the finding that neutrophils synthesize and may transfer tissue factor (Giesen et al. 1999) has been challenged (Osterud et al. 2000). Nevertheless, it is likely that blood-borne TF contributes to initiation and propagation of thrombosis given protection of mice lacking TF specifically on myeloid cells (von Bruhl et al. 2012). Furthermore, the association between thrombotic diseases and elevated levels of TF-bearing microparticles in blood are consistent with a role of blood-borne TF in thrombosis (Zwicker et al. 2011).

A second mechanism by which the platelet-neutrophil axis contributes to initiation and propagation of thrombosis is through generation of NETs (Fuchs et al. 2010; Brill et al. 2012). NETs have been directly implicated in thrombosis as prevention of NET formation using mice deficient in PAD4 (Martinod et al. 2013), which cannot undergo the histone modification required for chromatin decondensation in NET formation and disintegration of NETs by DNAse (Fuchs et al. 2010) reduced the thrombus load in mouse models. Also, NETs have been demonstrated in human thrombi (Stakos et al. 2015; Savchenko et al. 2014) and NET components including nucleosomes, histones and cell-free DNA are elevated in patients with thrombotic disease (van Montfoort et al. 2013; Jimenez-Alcazar et al. 2017), although it has not been established whether this is a consequence of the event or that in humans elevated NET components indicate a risk for a future thrombotic event. NETs appear to drive thrombus formation by multiple mechanisms including TF-mediated 
initiation of coagulation, FXII-mediated initiation of coagulation, adhesion of platelets, recruitment of platelet adhesive proteins such as VWF, recruitment of red blood cells and inhibition of clot breakdown (Martinod and Wagner 2014; Gould et al. 2015). Although it has been well established that NETs support thrombin generation in vitro and in vivo, the mechanisms involved are incompletely understood and partly controversial. A recent study found that NET components but not NETs themselves, are procoagulant in vitro (Noubouossie et al. 2017). Indeed, a number of studies have shown activation or amplification of coagulation by cell-free DNA but part of these results have been challenged as procoagulant effects of isolated DNA appear to be related to activators co-purified with the DNA, notably silica particles (Smith et al. 2017). In addition, histones have been shown to drive thrombin generation and inhibit protein C-mediated anticoagulant responses (Ammollo et al. 2011).

A third mechanism linking the platelet-neutrophil axis to thrombosis relates to neutrophil constituents modulating hemostasis. For instance, neutrophil cathepsin $\mathrm{G}$ and elastase inactivate natural anticoagulant systems including tissue factor pathway inhibitor, thrombomodulin and antithrombin (von Bruhl et al. 2012; MacGregor et al. 1997; Jordan et al. 1989). In addition, neutrophil oxidants inactivate thrombomodulin and ADAMTS13 (Glaser et al. 1992; Wang et al. 2015), while VWF modification by neutrophil oxidants renders it resistant to ADAMTS13 cleavage (Chen et al. 2010). Finally, neutrophil peptides ( $\alpha$ defensins) have also been shown to inhibit VWF cleavage by ADAMTS13 (Pillai et al. 2016). Thus, inactivation of key anticoagulant systems and inhibition of ADAMTS13-mediated regulation of VWF-dependent thrombus formation all contribute to procoagulant effects of neutrophils. However, neutrophil cathepsin $\mathrm{G}$ and elastase are able to proteolyse VWF, which may compensate for the defect in ADAMTS13-mediated cleavage (Bonnefoy and Legrand 2000; Raife et al. 2009).

\section{Platelet-neutrophil interactions in atherosclerosis}

Platelets have long been implicated in acute coronary events. Their key role is evidenced by the success of platelet inhibitory drug in treatment and prevention of acute arterial thrombotic events (Jamasbi et al. 2017). Additionally, platelets have been implicated in atherogenesis and platelet adhesion to activated endothelium is a very early event in the process of atherogenesis and drives subsequent proinflammatory responses leading to plaque formation (Gawaz et al. 2005). Attraction of leukocytes, particularly monocytes, to the developing atherosclerotic lesion has also long been recognized as a key event in atherogenesis (Gistera and Hansson 2017). Platelets facilitate monocyte adhesion to and transmigration through the endothelial cell layer and facilitate the formation of foam cells from these macrophages. The role of the neutrophil in atherogenesis has long escaped attention due to the pivotal role of monocytes in the process. However, several lines of evidence suggest neutrophils and platelet-neutrophil interactions to also be key players in atherogenesis and acute coronary events. Firstly, neutrophil counts are predictors of future coronary events (Shah et al. 2017; Horne et al. 2005) and local neutrophil accumulation is associated with the outcome of a coronary event (Distelmaier et al. 2014). Secondly, animal models have shown NET formation in the developing atherosclerotic lesion (Warnatsch et al. 2015), while inhibition of PAD4 (which is required for NET formation) decreased the size of the atherosclerotic lesion indicating that NET formation is a driver of atherogenesis (Knight et al. 2014). Indeed, in humans, NET components have been associated with the severity of atherosclerosis and the future risk of cardiac events (Borissoff et al. 2013). Finally, NETs have been identified in coronary thrombi obtained during thrombectomy or from patients with stent thrombosis (Mangold et al. 2015; Riegger et al. 2016). It is incompletely understood how NETs drive atherogenesis but mechanisms may include activation of plasmacytoid dendritic cells resulting in a type I interferon response (Doring et al. 2012), activation of macrophages that subsequently release inflammatory cytokines (Warnatsch et al. 2015), or enhancement of endothelial dysfunction (CarmonaRivera et al. 2015).

\section{Platelet-neutrophil interactions in tissue injury and repair}

Sterile tissue injury as for example encountered in injury by toxins (Miyakawa et al. 2015), ischemia/reperfusion injury (Tamura et al. 2012), or sterile traumatic injury (Slaba et al. 2015) results in recruitment of platelets in response to endothelial injury. Neutrophils are also recruited to sites of sterile injury and consequent platelet-neutrophil interactions will contribute to exacerbation of injury or to repair, depending on the context.

For example, acetaminophen-induced liver injury results in an influx of platelets and neutrophils in the liver microcirculation (Miyakawa et al. 2015). Depletion of either platelets or neutrophils decreases hepatocellular injury (Liu et al. 2006; Miyakawa et al. 2015). As depletion of platelets also decreases neutrophil influx, it may be that platelet-neutrophil crosstalk is involved in driving acetaminophen-induced liver injury. Of note, although it has been demonstrated that neutrophil depletion decreases acetaminophen-induced hepatocellular injury, these results have been questioned (Jaeschke and Liu 2007) and it has been suggested that neutrophils do not directly contribute to injury but are only involved in tissue repair following acetaminophen intoxication (Williams et al. 2014). Similarly, platelets have been shown to drive 
neutrophil-mediated liver damage following acute alphanaphthylisothiocyanate intoxication (Sullivan et al. 2010).

Platelets and neutrophils have been implicated as drivers of ischemia/reperfusion injury in liver (Yadav et al. 1999), kidney (Jansen et al. 2017), heart (Bonaventura et al. 2016) and lungs (Sayah et al. 2015) and platelet-neutrophil crosstalk has been suggested to be an important contributor of injury. Recent studies have shown NET formation to contribute to ischemia/reperfusion injury as inhibitors of NET formation or NET degradation by DNAse reduced injury in experimental animal models (Nakazawa et al. 2017; Sayah et al. 2015; Ge et al. 2015; Huang et al. 2015). Such studies indicate that NETs are not only involved in infection and thrombosis but also reinforces the notion that NETs drive non-infectious, nonthrombotic disease (Jorch and Kubes 2017). The exact mechanisms by which NETs drive ischemia/reperfusion injury are unknown but part of the mechanism may involve intravascular thrombus formation, as inhibitors of coagulation activation have also been shown to reduce ischemia/reperfusion injury (Okajima et al. 2002; Tillet et al. 2015). Studies in humans have also shown the formation of NETs in transplanted lungs and it has been suggested that NET formation could lead to acute graft failure (Sayah et al. 2015).

Platelets trigger the release of NETs in a model of experimental transfusion-associated acute lung injury and thereby aggravate disease (Caudrillier et al. 2012). Pulmonary injury was substantially decreased by NET degradation by DNAse, platelet inhibition or an anti-histone antibody. Importantly, these interventions improved survival from $\sim 50 \%$ to $100 \%$ in this model.

Platelet-neutrophil interactions have been shown to facilitate repair in a model of heat-induced liver injury (Slaba et al. 2015). Specifically, it was shown that platelets immediately attached to the endothelium adjacent to the site of injury in a $\alpha \mathrm{IIb} \beta 3$-dependent manner. These platelets were required for subsequent neutrophil influx and these neutrophils assisted in the wound-healing response. Importantly, very few NETs were generated in this model, showing that platelet-neutrophil interactions that are physiologically relevant do not necessarily lead to formation of NETs.

Platelets are well known to be required for liver regeneration following partial hepatectomy and it has been suggested that growth factors stored within platelet granules drive platelet-mediated liver regeneration (Lesurtel et al. 2006; Starlinger and Assinger 2016; Starlinger et al. 2014; Matsuo et al. 2008). However, since both neutrophils and platelets are required for liver regeneration following partial hepatectomy (Selzner et al. 2003; Lesurtel et al. 2006), it has been suggested that the mechanism by which platelets stimulate liver regeneration may be through leukocyte recruitment, similar to that demonstrated in the model of thermal liver injury (Lisman and Porte 2016).
Finally, NETs have also been demonstrated to contribute to organ injury in sepsis (Czaikoski et al. 2016), which may in part be due to deleterious effects of NET formation and subsequent intravascular coagulation on the microcirculation (McDonald et al. 2017). Treatment with DNAse also reduced organ damage in this setting (Czaikoski et al. 2016).

\section{The platelet-neutrophil interaction: a therapeutic target?}

Experimental and clinical evidence for a role of platelet-neutrophil crosstalk in a variety of clinical conditions including inflammation, thrombosis, atherosclerosis and tissue injury is rapidly emerging. Agents blocking PSGL-1, P-selectin, or MAC-1 that have pleiotropic effects that include inhibition of platelet-neutrophil interactions have been trialed in humans (Mertens et al. 2006; Stahli et al. 2016; Jones 2000) but are no longer in clinical development as clinical studies did not show a benefit of these agents. Given the key role of NETs in many clinical situations in which the platelet-leukocyte interaction is involved, it may be that inhibitors of NET formation or agents aimed at dissolving NETs could reignite the interest in agents aimed at blocking platelet-neutrophil interplay. Indications for such agents could include venous and acute arterial thrombosis, disseminated intravascular coagulation and various types of NET-mediated organ injury such as ischemia/reperfusion injury and transfusion-associated acute lung injury. In considering targeting NETs therapeutically, it should be remembered that NETs are likely required for fighting severe infection. It has been suggested that agents targeting NETs would be safe in the absence of overt infection but that concomitant administration of antibiotics would be indicated in cases of an infection (Martinod and Wagner 2014). Other diseases in which NETs have been implicated but which have not been discussed in this review include systemic lupus erythematosus, rheumatoid arthritis, diabetes, vasculitis and cancer (Jorch and Kubes 2017). Whether pharmacological targeting of NETs will be beneficial in these chronic diseases is an open question but clearly the risk of infection may hamper chronic use of such agents.

Inhibitors of PAD4 may have merit given the key role of PAD4 in NET formation and the intact NET-independent antiinflammatory properties of PAD4-deficient neutrophils (Li et al. 2010; Martinod and Wagner 2014). Alternatively, DNAseI, which has been shown to efficiently clear thrombi and decreased NET-mediated injury in experimental animal models may have merit, particularly since DNAseI is an FDA-approved drug (Pulmozyme, inhaled using a nebulizer for cystic fibrosis) and has also been trialed as an intravenous drug (Davis et al. 1999).

A clear advantage of targeting NETs in thrombotic syndromes is the lack of effect of the intervention on 


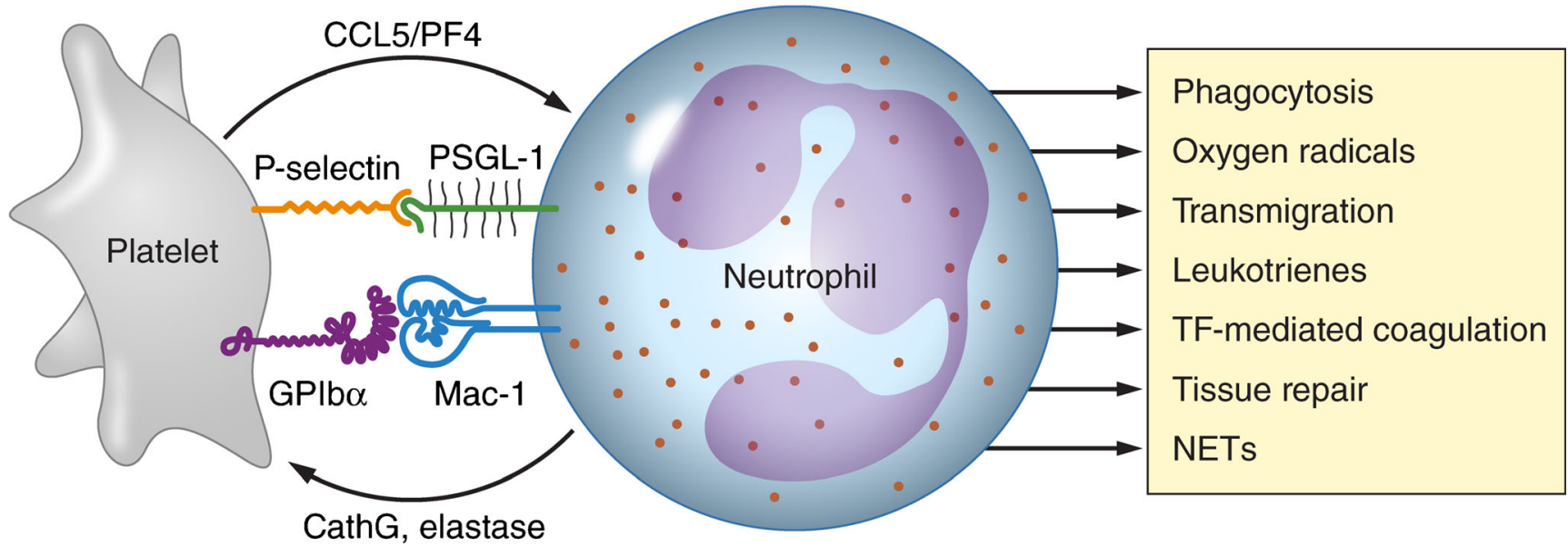

Fig. 1 The mode of interaction of platelets and neutrophils and the consequences of this interaction. Shown are the major receptor-ligand couples involved in the platelet-neutrophil interaction (P-selectinPSGL1 and GPIb $\alpha-M a c-1)$ and pathways by which platelets enhance leukocyte activation (by release of CCL5 and PF4) and by which neutrophils stimulate platelet activation (by release of elastase and cathepsin G, CathG). Downstream effects of the platelet-neutrophil

physiological hemostasis. As bleeding is an important side effect of current therapies for venous and arterial thrombosis and disseminated intravascular coagulation, the development of agents with a better risk/benefit ratio in terms of thrombotic potency versus bleeding risk would be a significant improvement.

\section{Conclusions}

Although platelets are traditionally seen as key players in thrombosis and hemostasis and neutrophils as prime inflammatory cells, recent data demonstrate a complex interplay between these cells with important immune functions for platelets and a clear role of neutrophils in thrombotic diseases. The prime mode of interaction between platelets and neutrophils and the downstream effects of this interaction are summarized in Fig. 1. The mechanisms by which the platelet-neutrophil interplay contributes to important infectious and thrombotic pathologies are only beginning to be explored, as is the role of these interactions in organ injury and repair. The discovery of NETs and the demonstration of the role of NETs in infection and thrombosis has provided clues for radical improvements in clinical strategies to combat infection, thrombosis and other diseases in which NETs are thought to play a role.

Open Access This article is distributed under the terms of the Creative Commons Attribution 4.0 International License (http:// creativecommons.org/licenses/by/4.0/), which permits unrestricted use, distribution and reproduction in any medium, provided you give appropriate credit to the original author(s) and the source, provide a link to the Creative Commons license and indicate if changes were made. interaction include increased leucocyte phagocytic activity, increased production of reactive oxygen species, increased transmigration of leukocytes over the endothelial cell lining, production of various bioactive leukotrienes, activation of coagulation via tissue factor $(T F)$, leukocyte-mediated tissue repair and generation of neutrophil extracellular traps $(N E T S)$. Professional illustration by Patrick Lane, ScEYEnce Studios

\section{References}

Ammollo CT, Semeraro F, Xu J, Esmon NL, Esmon CT (2011) Extracellular histones increase plasma thrombin generation by impairing thrombomodulin-dependent protein $\mathrm{C}$ activation. $\mathrm{J}$ Thromb Haemost 9:1795-1803

Assinger A, Laky M, Schabbauer G, Hirschl AM, Buchberger E, Binder BR, Volf I (2011) Efficient phagocytosis of periodontopathogens by neutrophils requires plasma factors, platelets and TLR2. J Thromb Haemost 9:799-809

Bonaventura A, Montecucco F, Dallegri F (2016) Cellular recruitment in myocardial ischaemia/reperfusion injury. Eur J Clin Investig 46: 590-601

Bonnefoy A, Legrand C (2000) Proteolysis of subendothelial adhesive glycoproteins (fibronectin, thrombospondin, and von Willebrand factor) by plasmin, leukocyte cathepsin $\mathrm{G}$, and elastase. Thromb Res 98:323-332

Borissoff JI, Joosen IA, Versteylen MO, Brill A, Fuchs TA, Savchenko AS, Gallant M, Martinod K, Ten Cate H, Hofstra L, Crijns HJ, Wagner DD, Kietselaer BLJH (2013) Elevated levels of circulating DNA and chromatin are independently associated with severe coronary atherosclerosis and a prothrombotic state. Arterioscler Thromb Vasc Biol 33:2032-2040

Bouchard BA, Mann KG, Butenas S (2010) No evidence for tissue factor on platelets. Blood 116:854-855

Brill A, Fuchs TA, Savchenko AS, Thomas GM, Martinod K, De Meyer SF, Bhandari AA, Wagner DD (2012) Neutrophil extracellular traps promote deep vein thrombosis in mice. J Thromb Haemost 10:136144

Brinkmann V, Reichard U, Goosmann C, Fauler B, Uhlemann Y, Weiss DS, Weinrauch Y, Zychlinsky A (2004) Neutrophil extracellular traps kill bacteria. Science 303:1532-1535

Butenas S, Bouchard BA, Brummel-Ziedins KE, Parhami-Seren B, Mann KG (2005) Tissue factor activity in whole blood. Blood 105:2764 2770

Camera M, Frigerio M, Toschi V, Brambilla M, Rossi F, Cottell DC, Maderna P, Parolari A, Bonzi R, De Vincenti O, Tremoli E (2003) Platelet activation induces cell-surface immunoreactive tissue factor 
expression, which is modulated differently by antiplatelet drugs. Arterioscler Thromb Vasc Biol 23:1690-1696

Carestia A, Kaufman T, Rivadeneyra L, Landoni VI, Pozner RG, Negrotto S, D'Atri LP, Gomez RM, Schattner M (2016) Mediators and molecular pathways involved in the regulation of neutrophil extracellular trap formation mediated by activated platelets. J Leukoc Biol 99:153-162

Carmona-Rivera C, Zhao W, Yalavarthi S, Kaplan MJ (2015) Neutrophil extracellular traps induce endothelial dysfunction in systemic lupus erythematosus through the activation of matrix metalloproteinase-2. Ann Rheum Dis 74:1417-1424

Caudrillier A, Kessenbrock K, Gilliss BM, Nguyen JX, Marques MB, Monestier M, Toy P, Werb Z, Looney MR (2012) Platelets induce neutrophil extracellular traps in transfusion-related acute lung injury. J Clin Invest 122:2661-2671

Chen VM, Hogg PJ (2013) Encryption and decryption of tissue factor. J Thromb Haemost 11(Suppl 1):277-284

Chen J, Fu X, Wang Y, Ling M, McMullen B, Kulman J, Chung DW, Lopez JA (2010) Oxidative modification of von Willebrand factor by neutrophil oxidants inhibits its cleavage by ADAMTS13. Blood 115:706-712

Cimmino G, Golino P, Badimon JJ (2011) Pathophysiological role of blood-borne tissue factor: should the old paradigm be revisited? Intern Emerg Med 6:29-34

Clark SR, Ma AC, Tavener SA, McDonald B, Goodarzi Z, Kelly MM, Patel KD, Chakrabarti S, McAvoy E, Sinclair GD, Keys EM, AllenVercoe E, Devinney R, Doig CJ, Green FH, Kubes P (2007) Platelet TLR4 activates neutrophil extracellular traps to ensnare bacteria in septic blood. Nat Med 13:463-469

Czaikoski PG, Mota JM, Nascimento DC, Sonego F, Castanheira FV, Melo PH, Scortegagna GT, Silva RL, Barroso-Sousa R, Souto FO, Pazin-Filho A, Figueiredo F, Alves-Filho JC, Cunha FQ (2016) Neutrophil extracellular traps induce organ damage during experimental and clinical sepsis. PLoS ONE 11:e0148142

Darbousset R, Thomas GM, Mezouar S, Frere C, Bonier R, Mackman N, Renne T, Dignat-George F, Dubois C, Panicot-Dubois L (2012) Tissue factor-positive neutrophils bind to injured endothelial wall and initiate thrombus formation. Blood 120:2133-2143

Davis JC Jr, Manzi S, Yarboro C, Rairie J, Mcinnes I, Averthelyi D, Sinicropi D, Hale VG, Balow J, Austin H, Boumpas DT, Klippel JH (1999) Recombinant human Dnase I (rhDNase) in patients with lupus nephritis. Lupus 8:68-76

de Stoppelaar SF, van 't Veer C, Claushuis TA, Albersen BJ, Roelofs JJ, van der Poll T (2014) Thrombocytopenia impairs host defense in gram-negative pneumonia-derived sepsis in mice. Blood 124:37813790

Deniset JF, Kubes P (2016) Recent advances in understanding neutrophils. F1000Res 5:2912

Distelmaier K, Winter MP, Dragschitz F, Redwan B, Mangold A, Gleiss A, Perkmann T, Maurer G, Adlbrecht C, Lang IM (2014) Prognostic value of culprit site neutrophils in acute coronary syndrome. Eur J Clin Investig 44:257-265

Doring Y, Manthey HD, Drechsler M, Lievens D, Megens RT, Soehnlein O, Busch M, Manca M, Koenen RR, Pelisek J, Daemen MJ, Lutgens E, Zenke M, Binder CJ, Weber C, Zernecke A (2012) Auto-antigenic protein-DNA complexes stimulate plasmacytoid dendritic cells to promote atherosclerosis. Circulation 125:16731683

Etulain J, Martinod K, Wong SL, Cifuni SM, Schattner M, Wagner DD (2015) P-selectin promotes neutrophil extracellular trap formation in mice. Blood 126:242-246

Fuchs TA, Brill A, Duerschmied D, Schatzberg D, Monestier M, Myers DD Jr, Wrobleski SK, Wakefield TW, Hartwig JH, Wagner DD (2010) Extracellular DNA traps promote thrombosis. Proc Natl Acad Sci U S A 107:15880-15885
Gawaz M, Fateh-Moghadam S, Pilz G, Gurland HJ, Werdan K (1995) Platelet activation and interaction with leucocytes in patients with sepsis or multiple organ failure. Eur J Clin Investig 25:843-851

Gawaz M, Langer H, May AE (2005) Platelets in inflammation and atherogenesis. J Clin Invest 115:3378-3384

Ge L, Zhou X, Ji WJ, Lu RY, Zhang Y, Zhang YD, Ma YQ, Zhao JH, Li YM (2015) Neutrophil extracellular traps in ischemia-reperfusion injury-induced myocardial no-reflow: therapeutic potential of DNase-based reperfusion strategy. Am J Physiol Heart Circ Physiol 308:H500-H509

Giesen PL, Rauch U, Bohrmann B, Kling D, Roque M, Fallon JT, Badimon JJ, Himber J, Riederer MA, Nemerson Y (1999) Bloodborne tissue factor: another view of thrombosis. Proc Natl Acad Sci U S A 96:2311-2315

Gistera A, Hansson GK (2017) The immunology of atherosclerosis. Nat Rev Nephrol 13:368-380

Glaser CB, Morser J, Clarke JH, Blasko E, McLean K, Kuhn I, Chang RJ, Lin JH, Vilander L, Andrews WH, Light DR (1992) Oxidation of a specific methionine in thrombomodulin by activated neutrophil products blocks cofactor activity. A potential rapid mechanism for modulation of coagulation. J Clin Invest 90:2565-2573

Goldsmith HL, Spain S (1984) Margination of leukocytes in blood flow through small tubes. Microvasc Res 27:204-222

Goldsmith HL, Bell DN, Spain S, McIntosh FA (1999) Effect of red blood cells and their aggregates on platelets and white cells in flowing blood. Biorheology 36:461-468

Gould TJ, Lysov Z, Liaw PC (2015) Extracellular DNA and histones: double-edged swords in immunothrombosis. J Thromb Haemost 13(Suppl 1):S82-S91

Gresele P, Dottorini M, Selli ML, Iannacci L, Canino S, Todisco T, Romano S, Crook P, Page CP, Nenci GG (1993) Altered platelet function associated with the bronchial hyperresponsiveness accompanying nocturnal asthma. J Allergy Clin Immunol 91:894-902

Gros A, Ollivier V, Ho-Tin-Noe B (2015a) Platelets in inflammation: regulation of leukocyte activities and vascular repair. Front Immunol 5:678

Gros A, Syvannarath V, Lamrani L, Ollivier V, Loyau S, Goerge T, Nieswandt B, Jandrot-Perrus M, Ho-Tin-Noe B (2015b) Single platelets seal neutrophil-induced vascular breaches via GPVI during immune-complex-mediated inflammation in mice. Blood 126: $1017-1026$

Gross PL, Furie BC, Merrill-Skoloff G, Chou J, Furie B (2005) Leukocyte-versus microparticle-mediated tissue factor transfer during arteriolar thrombus development. J Leukoc Biol 78:1318-1326

Hamburger SA, McEver RP (1990) GMP-140 mediates adhesion of stimulated platelets to neutrophils. Blood 75:550-554

Heestermans M, Salloum-Asfar S, Salvatori D, Laghmani e H, Luken BM, Zeerleder SS, Spronk HM, Korporaal SJ, Wagenaar GT, Reitsma PH, van Vlijmen BJ (2016) Role of platelets, neutrophils, and factor XII in spontaneous venous thrombosis in mice. Blood 127:2630-2637

Horne BD, Anderson JL, John JM, Weaver A, Bair TL, Jensen KR, Renlund DG, Muhlestein JB, Intermountain Heart Collaborative Study Group (2005) Which white blood cell subtypes predict increased cardiovascular risk? J Am Coll Cardiol 45:1638-1643

Houdijk WP, de Groot PG, Nievelstein PF, Sakariassen KS, Sixma JJ (1986) Subendothelial proteins and platelet adhesion. Von Willebrand factor and fibronectin, not thrombospondin, are involved in platelet adhesion to extracellular matrix of human vascular endothelial cells. Arteriosclerosis 6:24-33

Huang H, Tohme S, Al-Khafaji AB, Tai S, Loughran P, Chen L, Wang S, Kim J, Billiar T, Wang Y, Tsung A (2015) Damage-associated molecular pattern-activated neutrophil extracellular trap exacerbates sterile inflammatory liver injury. Hepatology 62:600-614 
Hurley SM, Kahn F, Nordenfelt P, Morgelin M, Sorensen OE, Shannon O (2015) Platelet-dependent neutrophil function is dysregulated by $M$ protein from streptococcus pyogenes. Infect Immun 83:3515-3525

Jaeschke H, Liu J (2007) Neutrophil depletion protects against murine acetaminophen hepatotoxicity: another perspective. Hepatology 45: $1588-1589$

Jamasbi J, Ayabe K, Goto S, Nieswandt B, Peter K, Siess W (2017) Platelet receptors as therapeutic targets: past, present and future. Thromb Haemost 117:1249-1257

Jansen MP, Emal D, Teske GJ, Dessing MC, Florquin S, Roelofs JJ (2017) Release of extracellular DNA influences renal ischemia reperfusion injury by platelet activation and formation of neutrophil extracellular traps. Kidney Int 91:352-364

Jenne CN, Wong CH, Zemp FJ, McDonald B, Rahman MM, Forsyth PA, McFadden G, Kubes P (2013) Neutrophils recruited to sites of infection protect from virus challenge by releasing neutrophil extracellular traps. Cell Host Microbe 13:169-180

Jimenez-Alcazar M, Kim N, Fuchs TA (2017) Circulating Extracellular DNA: Cause or Consequence of Thrombosis? Semin Thromb Hemost 43:553-561

Jones R (2000) Rovelizumab (ICOS Corp). IDrugs 3:442-446

Jorch SK, Kubes P (2017) An emerging role for neutrophil extracellular traps in noninfectious disease. Nat Med 23:279-287

Jordan RE, Nelson RM, Kilpatrick J, Newgren JO, Esmon PC, Fournel MA (1989) Inactivation of human antithrombin by neutrophil elastase. Kinetics of the heparin-dependent reaction. J Biol Chem 264: 10493-10500

Knight JS, Luo W, O'Dell AA, Yalavarthi S, Zhao W, Subramanian V, Guo C, Grenn RC, Thompson PR, Eitzman DT, Kaplan MJ (2014) Peptidylarginine deiminase inhibition reduces vascular damage and modulates innate immune responses in murine models of atherosclerosis. Circ Res 114:947-956

Kuijper PH, Gallardo Torres HI, van der Linden JA, Lammers JW, Sixma JJ, Koenderman L, Zwaginga JJ (1996) Platelet-dependent primary hemostasis promotes selectin- and integrin-mediated neutrophil adhesion to damaged endothelium under flow conditions. Blood 87: 3271-3281

Lecut C, Faccinetto C, Delierneux C, van Oerle R, Spronk HM, Evans RJ, El Benna J, Bours V, Oury C (2012) ATP-gated P2X1 ion channels protect against endotoxemia by dampening neutrophil activation. J Thromb Haemost 10:453-465

Lesurtel M, Graf R, Aleil B, Walther DJ, Tian Y, Jochum W, Gachet C, Bader M, Clavien PA (2006) Platelet-derived serotonin mediates liver regeneration. Science 312:104-107

Li P, Li M, Lindberg MR, Kennett MJ, Xiong N, Wang Y (2010) PAD4 is essential for antibacterial innate immunity mediated by neutrophil extracellular traps. J Exp Med 207:1853-1862

Lisman T, Porte RJ (2016) Mechanisms of platelet-mediated liver regeneration. Blood 128:625-629

Liu ZX, Han D, Gunawan B, Kaplowitz N (2006) Neutrophil depletion protects against murine acetaminophen hepatotoxicity. Hepatology 43:1220-1230

Looney MR, Nguyen JX, Hu Y, Van Ziffle JA, Lowell CA, Matthay MA (2009) Platelet depletion and aspirin treatment protect mice in a twoevent model of transfusion-related acute lung injury. J Clin Invest 119:3450-3461

MacGregor IR, Perrie AM, Donnelly SC, Haslett C (1997) Modulation of human endothelial thrombomodulin by neutrophils and their release products. Am J Respir Crit Care Med 155:47-52

Mangold A, Alias S, Scherz T, Hofbauer T, Jakowitsch J, Panzenbock A, Simon D, Laimer D, Bangert C, Kammerlander A, Mascherbauer J, Winter MP, Distelmaier K, Adlbrecht C, Preissner KT, Lang IM (2015) Coronary neutrophil extracellular trap burden and deoxyribonuclease activity in ST-elevation acute coronary syndrome are predictors of ST-segment resolution and infarct size. Circ Res 116: $1182-1192$
Marcus AJ, Safier LB, Ullman HL, Broekman MJ, Islam N, Oglesby TD, Gorman RR (1984) 12S,20-dihydroxyicosatetraenoic acid: a new icosanoid synthesized by neutrophils from 12S-hydroxyicosatetraenoic acid produced by thrombin- or collagen-stimulated platelets. Proc Natl Acad Sci U S A 81:903-907

Marcus AJ, Safier LB, Ullman HL, Islam N, Broekman MJ, von Schacky C (1987) Studies on the mechanism of omega-hydroxylation of platelet 12-hydroxyeicosatetraenoic acid (12-HETE) by unstimulated neutrophils. J Clin Invest 79:179-187

Marcus AJ, Safier LB, Ullman HL, Islam N, Broekman MJ, Falck JR, Fischer S, von Scehacky C (1988) Platelet-neutrophil interactions. (12S)-hydroxyeicosatetraen-1,20-dioic acid: a new eicosanoid synthesized by unstimulated neutrophils from (12S)-20dihydroxyeicosatetraenoic acid. J Biol Chem 263:2223-2229

Martinod K, Wagner DD (2014) Thrombosis: tangled up in NETs. Blood 123:2768-2776

Martinod K, Demers M, Fuchs TA, Wong SL, Brill A, Gallant M, Hu J, Wang Y, Wagner DD (2013) Neutrophil histone modification by peptidylarginine deiminase 4 is critical for deep vein thrombosis in mice. Proc Natl Acad Sci U S A 110:8674-8679

Matsuo R, Ohkohchi N, Murata S, Ikeda O, Nakano Y, Watanabe M, Hisakura K, Myronovych A, Kubota T, Narimatsu H, Ozaki M (2008) Platelets strongly induce hepatocyte proliferation with IGF1 and HGF in vitro. J Surg Res 145:279-286

Maugeri N, Evangelista V, Celardo A, Dell'Elba G, Martelli N, Piccardoni P, de Gaetano G, Cerletti C (1994) Polymorphonuclear leukocyteplatelet interaction: role of $\mathrm{P}$-selectin in thromboxane $\mathrm{B} 2$ and leukotriene $\mathrm{C} 4$ cooperative synthesis. Thromb Haemost 72:450-456

Maugeri N, Campana L, Gavina M, Covino C, De Metrio M, Panciroli C, Maiuri L, Maseri A, D'Angelo A, Bianchi ME, Rovere-Querini P, Manfredi AA (2014) Activated platelets present high mobility group box 1 to neutrophils, inducing autophagy and promoting the extrusion of neutrophil extracellular traps. J Thromb Haemost 12:20742088

McCulloch RK, Croft KD, Vandongen R (1992) Enhancement of platelet 12-HETE production in the presence of polymorphonuclear leukocytes during calcium ionophore stimulation. Biochim Biophys Acta 1133:142-146

McDonald B, Davis RP, Kim SJ, Tse M, Esmon CT, Kolaczkowska E, Jenne CN (2017) Platelets and neutrophil extracellular traps collaborate to promote intravascular coagulation during sepsis in mice. Blood 129:1357-1367

Mertens P, Maes A, Nuyts J, Belmans A, Desmet W, Esplugas E, Charlier F, Figueras J, Sambuceti G, Schwaiger M, Mortelmans L, Van de Werf F, PSALM investigators (2006) Recombinant P-selectin glycoprotein ligand-immunoglobulin, a P-selectin antagonist, as an adjunct to thrombolysis in acute myocardial infarction. The P-selectin antagonist limiting Myonecrosis (PSALM) trial. Am Heart J 152: 125.e1-125.e8

Michelson AD, Barnard MR, Krueger LA, Valeri CR, Furman MI (2001) Circulating monocyte-platelet aggregates are a more sensitive marker of in vivo platelet activation than platelet surface P-selectin: studies in baboons, human coronary intervention, and human acute myocardial infarction. Circulation 104:1533-1537

Mihara K, Ramachandran R, Renaux B, Saifeddine M, Hollenberg MD (2013) Neutrophil elastase and proteinase-3 trigger G protein-biased signaling through proteinase-activated receptor-1 (PAR1). J Biol Chem 288:32979-32990

Miyakawa K, Joshi N, Sullivan BP, Albee R, Brandenberger C, Jaeschke H, McGill MR, Scott MA, Ganey PE, Luyendyk JP, Roth RA (2015) Platelets and protease-activated receptor-4 contribute to acetaminophen-induced liver injury in mice. Blood 126:1835-1843

Moore KL, Patel KD, Bruehl RE, Li F, Johnson DA, Lichenstein HS, Cummings RD, Bainton DF, McEver RP (1995) P-selectin glycoprotein ligand-1 mediates rolling of human neutrophils on $\mathrm{P}$ selectin. J Cell Biol 128:661-671 
Muller I, Klocke A, Alex M, Kotzsch M, Luther T, Morgenstern E, Zieseniss S, Zahler S, Preissner K, Engelmann B (2003) Intravascular tissue factor initiates coagulation via circulating microvesicles and platelets. FASEB J 17:476-478

Nakazawa D, Kumar SV, Marschner J, Desai J, Holderied A, Rath L, Kraft F, Lei Y, Fukasawa Y, Moeckel GW, Angelotti ML, Liapis H, Anders HJ (2017) Histones and neutrophil extracellular traps enhance tubular necrosis and remote organ injury in ischemic AKI. J Am Soc Nephrol 28:1753-1768

Noubouossie DF, Whelihan MF, Yu YB, Sparkenbaugh E, Pawlinski R, Monroe DM, Key NS (2017) In vitro activation of coagulation by human neutrophil DNA and histone proteins but not neutrophil extracellular traps. Blood 129:1021-1029

Okajima K, Harada N, Kushimoto S, Uchiba M (2002) Role of microthrombus formation in the development of ischemia/ reperfusion-induced liver injury in rats. Thromb Haemost 88:473480

Osterud B, Olsen JO (2013) Human platelets do not express tissue factor. Thromb Res 132:112-115

Osterud B, Rao LV, Olsen JO (2000) Induction of tissue factor expression in whole blood: lack of evidence for the presence of tissue factor expression in granulocytes. Thromb Haemost 83:861-867

Ott I, Neumann FJ, Gawaz M, Schmitt M, Schomig A (1996) Increased neutrophil-platelet adhesion in patients with unstable angina. Circulation 94:1239-1246

Page C, Pitchford S (2013) Neutrophil and platelet complexes and their relevance to neutrophil recruitment and activation. Int Immunopharmacol 17:1176-1184

Palabrica T, Lobb R, Furie BC, Aronovitz M, Benjamin C, Hsu YM, Sajer SA, Furie B (1992) Leukocyte accumulation promoting fibrin deposition is mediated in vivo by P-selectin on adherent platelets. Nature 359:848-851

Pamuk GE, Vural O, Turgut B, Demir M, Umit H, Tezel A (2006) Increased circulating platelet-neutrophil, platelet-monocyte complexes, and platelet activation in patients with ulcerative colitis: a comparative study. Am J Hematol 81:753-759

Panes O, Matus V, Saez CG, Quiroga T, Pereira J, Mezzano D (2007) Human platelets synthesize and express functional tissue factor. Blood 109:5242-5250

Pervushina O, Scheuerer B, Reiling N, Behnke L, Schroder JM, Kasper B, Brandt E, Bulfone-Paus S, Petersen F (2004) Platelet factor 4/CXCL4 induces phagocytosis and the generation of reactive oxygen metabolites in mononuclear phagocytes independently of Gi protein activation or intracellular calcium transients. J Immunol 173:2060-2067

Peters MJ, Dixon G, Kotowicz KT, Hatch DJ, Heyderman RS, Klein NJ (1999) Circulating platelet-neutrophil complexes represent a subpopulation of activated neutrophils primed for adhesion, phagocytosis and intracellular killing. Br J Haematol 106:391-399

Peters-Golden M, Henderson WR Jr (2007) Leukotrienes. N Engl J Med 357:1841-1854

Pillai VG, Bao J, Zander CB, McDaniel JK, Chetty PS, Seeholzer SH, Bdeir K, Cines DB, Zheng XL (2016) Human neutrophil peptides inhibit cleavage of von Willebrand factor by ADAMTS13: a potential link of inflammation to TTP. Blood 128:110-119

Polanowska-Grabowska R, Wallace K, Field JJ, Chen L, Marshall MA, Figler R, Gear AR, Linden J (2010) P-selectin-mediated plateletneutrophil aggregate formation activates neutrophils in mouse and human sickle cell disease. Arterioscler Thromb Vasc Biol 30:23922399

Qiu Y, Ciciliano J, Myers DR, Tran R, Lam WA (2015) Platelets and physics: how platelets "feel" and respond to their mechanical microenvironment. Blood Rev 29:377-386

Raife TJ, Cao W, Atkinson BS, Bedell B, Montgomery RR, Lentz SR, Johnson GF, Zheng XL (2009) Leukocyte proteases cleave von
Willebrand factor at or near the ADAMTS13 cleavage site. Blood 114:1666-1674

Rauch U, Bonderman D, Bohrmann B, Badimon JJ, Himber J, Riederer MA, Nemerson Y (2000) Transfer of tissue factor from leukocytes to platelets is mediated by CD15 and tissue factor. Blood 96:170 175

Remuzzi A, Languino LR, Costantini V, Guardabasso V, de Gaetano G, Dejana E (1985) Platelet adhesion to subendothelium-effect of shear rate, hematocrit and platelet count on the dynamic equilibrium between platelets adhering to and detaching from the surface. Thromb Haemost 54:857-861

Riegger J, Byrne RA, Joner M, Chandraratne S, Gershlick AH, Ten Berg JM, Adriaenssens T, Guagliumi G, Godschalk TC, Neumann FJ, Trenk D, Feldman LJ, Steg PG, Desmet W, Alfonso F, Goodall AH, Wojdyla R, Dudek D, Philippi V, Opinaldo S, Titova A, Malik N, Cotton J, Jhagroe DA, Heestermans AA, Sinnaeve P, Vermeersch P, Valina C, Schulz C, Kastrati A, Massberg S, Prevention of Late Stent Thrombosis by an Interdisciplinary Global European Effort (PRESTIGE) Investigators (2016) Histopathological evaluation of thrombus in patients presenting with stent thrombosis. A multicenter European study: a report of the prevention of late stent thrombosis by an interdisciplinary global European effort consortium. Eur Heart J 37:1538-1549

Sambrano GR, Huang W, Faruqi T, Mahrus S, Craik C, Coughlin SR (2000) Cathepsin G activates protease-activated receptor-4 in human platelets. J Biol Chem 275:6819-6823

Savchenko AS, Martinod K, Seidman MA, Wong SL, Borissoff JI, Piazza G, Libby P, Goldhaber SZ, Mitchell RN, Wagner DD (2014) Neutrophil extracellular traps form predominantly during the organizing stage of human venous thromboembolism development. J Thromb Haemost 12:860-870

Sayah DM, Mallavia B, Liu F, Ortiz-Munoz G, Caudrillier A, Der Hovanessian A, Ross DJ, Lynch JP 3rd, Saggar R, Ardehali A, Lung Transplant Outcomes Group Investigators, Ware LB, Christie JD, Belperio JA, Looney MR (2015) Neutrophil extracellular traps are pathogenic in primary graft dysfunction after lung transplantation. Am J Respir Crit Care Med 191:455-463

Schwertz H, Tolley ND, Foulks JM, Denis MM, Risenmay BW, Buerke M, Tilley RE, Rondina MT, Harris EM, Kraiss LW, Mackman N, Zimmerman GA, Weyrich AS (2006) Signal-dependent splicing of tissue factor pre-mRNA modulates the thrombogenicity of human platelets. J Exp Med 203:2433-2440

Selak MA (1992) Neutrophil elastase potentiates cathepsin G-induced platelet activation. Thromb Haemost 68:570-576

Selzner N, Selzner M, Odermatt B, Tian Y, Van Rooijen N, Clavien PA (2003) ICAM-1 triggers liver regeneration through leukocyte recruitment and Kupffer cell-dependent release of TNF-alpha/IL-6 in mice. Gastroenterology 124:692-700

Shah AD, Denaxas S, Nicholas O, Hingorani AD, Hemingway H (2017) Neutrophil counts and initial presentation of 12 cardiovascular diseases: a CALIBER cohort study. J Am Coll Cardiol 69:1160-1169

Simon DI, Chen Z, Xu H, Li CQ, Dong J, McIntire LV, Ballantyne CM, Zhang L, Furman MI, Berndt MC, Lopez JA (2000) Platelet glycoprotein ibalpha is a counterreceptor for the leukocyte integrin mac-1 (CD11b/CD18). J Exp Med 192:193-204

Slaba I, Wang J, Kolaczkowska E, McDonald B, Lee WY, Kubes P (2015) Imaging the dynamic platelet-neutrophil response in sterile liver injury and repair in mice. Hepatology 62:1593-1605

Smith SA, Baker CJ, Gajsiewicz JM, Morrissey JH (2017) Silica particles contribute to the procoagulant activity of DNA and polyphosphate isolated using commercial kits. Blood 130:88-91

Soehnlein O, Steffens S, Hidalgo A, Weber C (2017) Neutrophils as protagonists and targets in chronic inflammation. Nat Rev Immunol 17:248-261

Sreeramkumar V, Adrover JM, Ballesteros I, Cuartero MI, Rossaint J, Bilbao I, Nacher M, Pitaval C, Radovanovic I, Fukui Y, McEver 
RP, Filippi MD, Lizasoain I, Ruiz-Cabello J, Zarbock A, Moro MA, Hidalgo A (2014) Neutrophils scan for activated platelets to initiate inflammation. Science 346:1234-1238

Stahli BE, Tardif JC, Carrier M, Gallo R, Emery RW, Robb S, Cournoyer D, Blondeau L, Johnson D, Mann J, Lesperance J, Guertin MC, L'Allier PL (2016) Effects of P-selectin antagonist Inclacumab in patients undergoing coronary artery bypass graft surgery: SELECTCABG trial. J Am Coll Cardiol 67:344-346

Stakos DA, Kambas K, Konstantinidis T, Mitroulis I, Apostolidou E, Arelaki S, Tsironidou V, Giatromanolaki A, Skendros P, Konstantinides S, Ritis K (2015) Expression of functional tissue factor by neutrophil extracellular traps in culprit artery of acute myocardial infarction. Eur Heart J 36:1405-1414

Starlinger P, Assinger A (2016) Defective intra-platelet vascular endothelial growth factor release is associated with liver dysfunction following partial hepatectomy. Hepatology 64:992-993

Starlinger P, Assinger A, Haegele S, Wanek D, Zikeli S, Schauer D, Birner P, Fleischmann E, Gruenberger B, Brostjan C, Gruenberger $\mathrm{T}$ (2014) Evidence for serotonin as a relevant inducer of liver regeneration after liver resection in humans. Hepatology 60:257-266

Sullivan BP, Wang R, Tawfik O, Luyendyk JP (2010) Protective and damaging effects of platelets in acute cholestatic liver injury revealed by depletion and inhibition strategies. Toxicol Sci 115:286294

Tamura T, Kondo T, Pak S, Nakano Y, Murata S, Fukunaga K, Ohkohchi N (2012) Interaction between Kupffer cells and platelets in the early period of hepatic ischemia-reperfusion injury-an in vivo study. $\mathrm{J}$ Surg Res 178:443-451

Tersteeg C, Heijnen HF, Eckly A, Pasterkamp G, Urbanus RT, Maas C, Hoefer IE, Nieuwland R, Farndale RW, Gachet C, de Groot PG, Roest M (2014) FLow-induced PRotrusions (FLIPRs): a plateletderived platform for the retrieval of microparticles by monocytes and neutrophils. Circ Res 114:780-791

Tillet S, Giraud S, Delpech PO, Thuillier R, Ameteau V, Goujon JM, Renelier B, Macchi L, Hauet T, Mauco G (2015) Kidney graft outcome using an anti-Xa therapeutic strategy in an experimental model of severe ischaemia-reperfusion injury. Br J Surg 102:132-142 discussion 142

van den Boogaard FE, Schouten M, de Stoppelaar SF, Roelofs JJ, Brands X, Schultz MJ, van't Veer C, van der Poll T (2015) Thrombocytopenia impairs host defense during murine Streptococcus Pneumoniae pneumonia. Crit Care Med 43:e75-e83

van Montfoort ML, Stephan F, Lauw MN, Hutten BA, Van Mierlo GJ, Solati S, Middeldorp S, Meijers JC, Zeerleder S (2013) Circulating nucleosomes and neutrophil activation as risk factors for deep vein thrombosis. Arterioscler Thromb Vasc Biol 33:147-151 von Bruhl ML, Stark K, Steinhart A, Chandraratne S, Konrad I, Lorenz M, Khandoga A, Tirniceriu A, Coletti R, Kollnberger M, Byrne RA, Laitinen I, Walch A, Brill A, Pfeiler S, Manukyan D, Braun S, Lange P, Riegger J, Ware J, Eckart A, Haidari S, Rudelius M, Schulz C, Echtler K, Brinkmann V, Schwaiger M, Preissner KT, Wagner DD, Mackman N, Engelmann B, Massberg S (2012) Monocytes, neutrophils, and platelets cooperate to initiate and propagate venous thrombosis in mice in vivo. J Exp Med 209:819-835

von Hundelshausen P, Koenen RR, Sack M, Mause SF, Adriaens W, Proudfoot AE, Hackeng TM, Weber C (2005) Heterophilic interactions of platelet factor 4 and RANTES promote monocyte arrest on endothelium. Blood 105:924-930

Wang Y, Chen J, Ling M, Lopez JA, Chung DW, Fu X (2015) Hypochlorous acid generated by neutrophils inactivates ADAMTS13: an oxidative mechanism for regulating ADAMTS13 proteolytic activity during inflammation. J Biol Chem 290:14221431

Wang Y, Gao H, Shi C, Erhardt PW, Pavlovsky A, Soloviev DA, Bledzka K, Ustinov V, Zhu L, Qin J, Munday AD, Lopez J, Plow E, Simon DI (2017) Leukocyte integrin mac-1 regulates thrombosis via interaction with platelet GPIbalpha. Nat Commun 8:15559

Warnatsch A, Ioannou M, Wang Q, Papayannopoulos V (2015) Inflammation. Neutrophil extracellular traps license macrophages for cytokine production in atherosclerosis. Science 349:316-320

Williams CD, Bajt ML, Sharpe MR, McGill MR, Farhood A, Jaeschke H (2014) Neutrophil activation during acetaminophen hepatotoxicity and repair in mice and humans. Toxicol Appl Pharmacol 275:122133

Xu XR, Zhang D, Oswald BE, Carrim N, Wang X, Hou Y, Zhang Q, Lavalle C, McKeown T, Marshall AH, Ni H (2016) Platelets are versatile cells: new discoveries in hemostasis, thrombosis, immune responses, tumor metastasis and beyond. Crit Rev Clin Lab Sci 53: 409-430

Yadav SS, Howell DN, Steeber DA, Harland RC, Tedder TF, Clavien PA (1999) P-selectin mediates reperfusion injury through neutrophil and platelet sequestration in the warm ischemic mouse liver. Hepatology 29:1494-1502

Zalavary S, Grenegard M, Stendahl O, Bengtsson T (1996) Platelets enhance fc(gamma) receptor-mediated phagocytosis and respiratory burst in neutrophils: the role of purinergic modulation and actin polymerization. J Leukoc Biol 60:58-68

Zwicker JI, Trenor CC 3rd, Furie BC, Furie B (2011) Tissue factorbearing microparticles and thrombus formation. Arterioscler Thromb Vasc Biol 31:728-733 